\title{
Lessons in Curriculum from Aldo Leopold's Education
}

\author{
by \\ Henry St. Maurice, Professor Emeritus of Education \\ University of Wisconsin - Stevens Point \\ hstmauri@uwsp.edu
}

Paper previously presented at the

Aldo Leopold Foundation Conference

Building a Land Ethic

Baraboo, WI

June 22, 2017 


\begin{abstract}
Using archival data, Leopold's secondary curricula at Burlington Iowa High School and The Lawrenceville (New Jersey) School are analyzed for knowledge and skills that are relevant to environmental educators. A list of literary and scientific texts was used to survey current students in colleges and universities to determine to what extent, if any, they have been included in contemporary curricula for environmental literacy. Specific recommendations are made for environmental educators.
\end{abstract}


Aldo Leopold's works have endured because they combine scientific rigor and practical applications in felicitous prose. Nearly seven decades after his untimely death, his contributions to ecological science, environmental literature, and ethics continue to serve as models for generations of scientists, scholars, practitioners, and activists. As an educator, I witness the power of his works every time a new generation of students reads A Sand County Almanac (SCA). His words live and his ideas grow across generations, cultures, and languages. They manifest his triad of ethical virtues in their own integrity, beauty, and stability.

This is a report of my exploration of a source of Leopold's enduring values. I have analyzed the curricula that Leopold encountered in his secondary schools, to find where and how he first learned knowledge and skills that he brought to his writings. In the first section, I present a background of curriculum history and specifics about the curricula in use at the times that he attended Burlington (IA) High School (BHS) and The Lawrenceville (NJ) School (TLS). In the second section, I surmise how certain parts of those curricula introduced knowledge and skills that prevailed in his writings up to last published work. In the third section, I report on a survey of contemporary undergraduate students, to show when they first encountered Leopold's and other works of environmental literature. In conclusion, I state what educators and activists could learn from the curricula that Leopold encountered in his schooling.

\section{Curriculum History \& Theory}

For as long as humans have learned their languages and cultures, questions about curriculum have been asked: What knowledge is of most worth? What should be taught to whom, by whom, when, how, and in what order? Kliebard (1995), in his magisterial history of the American public-school curriculum from 1893 to 1958, identified four interest groups whose curriculum theories comprise responses to those questions. He described them as: 
- Humanist scholars whose curricula were aimed to develop “....guardians of ancient tradition...";

- Developmentalist psychologists whose curricula were aimed to develop “... harmony with children's interests, needs, and learning patterns...";

- Social-efficiency sociologists whose curricula were aimed to develop “.... a coolly efficient smoothly running society..."; and

- Social meliorist policymakers whose curricula were aimed to develop "social change and social justice" (pp. 23-24).

Kliebard concluded that the American curriculum "was not the result of any decisive victory by any of the contending parties, but a loose, largely unarticulated and not very tidy compromise" (p. 25).

Leopold, who began his high-school education at BHS in 1901 when he was 14 years old, encountered compromises among all four types of curriculum in his schooling. BHS curricula were nonetheless predominately in the humanist tradition, as were curricula he encountered at TLS in 1904 to 1905, prior to his enrollment at Yale University (Meine, 2010, pp. 16 \& 34-35).

Before environmental education became a formal part of school curricula (Buell, 2001; Lotz-Sizitka et al., 2013; Reese, 1999), Leopold's studies included readings in humanistic and naturalistic texts at home and in school, as well as his eager pursuit of outdoor activities. As Meine summarized, "Leopold's true genius, even then, lay not inside the school [TLS] but in the fields around it" (ibid., p. 35). In combining his readings with activities, he was a pioneer in environmental literacy, recently defined as follows:

... distinct from simple awareness or immediate personal conduct because of its depth of information and the actual skills (i.e., thinking and doing) that are imparted. ... It starts 
out with framed information but also involves imparting the subject's underlying principles, the skills needed to investigate the subject, and an understanding of how to apply that information. Most real environmental education involves actual hands-on experience with a subject either in a lab or the field. (Coyle, 2005, p. xiii).

The same report ruefully concluded, “....very few people have sufficient environmental knowledge and skill to be considered environmentally literate. While there are no 'hard' numbers on the subject, an estimate of $1 \%$ to $2 \%$ of adults in America seems supportable" (ibid.).

Evidence of the development of Leopold's environmental literacy can be found in his home, his schools, and in his writings. His home library, now dispersed, included such philosophy as Thoreau's works, such non-fiction as Darwin's Voyage of the Beagle and von Humboldt's Kosmos, along with literary works by London, Whittier, Tennyson, and Emerson (Meine, passim; Brower, personal communication). His BHS curriculum, in extant documents, was divided into the following areas: First, the area entitled language, literature, and grammar included traditional humanist readings along with instruction in German and Latin languages including "plenty of Cicero" (Meine, personal communication). Also in the BHS curriculum was an area entitled history and geography, followed by an area entitled mathematics and science. In the BHS course of study, the only listed science was biology. Although BHS course descriptions were lost in a fire, surviving documents show an example of stated objects of eighth-grade nature study:

- To awaken and foster love of nature;

- To cultivate observation and comparison; and

- To get a knowledge of common things (Fultz, 1904, p. 57). 
From all accounts and archival collections of his school work (n.d.), Leopold met those objectives. His BHS studies were affected by overcrowding, in that the school enrolled 418 pupils in 1904 in a building with room for 300 and staffed by only 13 teachers (Fultz, 1904, pp. 4 \& 23). He attended mostly half-day recitations that perfectly suited his inclinations to go outdoors at every opportunity (Meine, p. 24).

The report of the high-school principal, couched in sunny approbations of progress, includes cautionary notes. First, despite five resignations, he stated,

I can truthfully say that there does not exist a body of teachers so free from petty jealousies, so unselfishly loyal to the best interests of the school, as the thirteen faithful, competent, teachers over whom I have the honor to preside in the Burlington High School (Ricker, in Fultz, 1904, pp. 26-27).

Leopold's high school was therefore dealing with a reported $38 \%$ turnover in its teaching force in addition to overcrowding. Both were sources of "increasing dissatisfaction" with its offerings. (ibid.). Nonetheless, Meine (p. 25) described the "lasting effect" of Leopold's English teacher, one Miss Rogers, as well as effects of nature-study and biology curricula in his choice of forestry as a major and career.

After much discussion between his parents, Leopold's mother prevailed upon a recommendation by an acquaintance to enroll him in TLS for the 1904-05 school year, to offer him opportunities not available in Iowa (Meine, p. 24). At TLS, he thrived in a traditional humanist curriculum. Physics was the only the science course on his transcript (Table 1). Table 1. Leopold's Lawrenceville School Transcript

\begin{tabular}{llll}
\hline Form & Course & Grades* $^{*}$ & Curriculum \\
\hline IV & Elocution & $3 \mathrm{~b}, 3 \mathrm{~b}, 1 \mathrm{a}$ & Original speaking \& debate \\
IV & English & $3 \mathrm{~b}, 1 \mathrm{~b}, 1 \mathrm{~b}$ & English literature \\
IV & English Review & $1 \mathrm{~b}, 1 \mathrm{a}, 1 \mathrm{~b}$ & \\
\hline
\end{tabular}




\begin{tabular}{llll}
\hline Form & Course & Grades* & Curriculum \\
\hline IV & English History & $1 \mathrm{~b}, 2 \mathrm{~b}, 2 \mathrm{~b}$ & \\
IV & Civics & $2 \mathrm{~b}$ & Vergil, Aeneid, six books \\
IV & Latin Text & $3 \mathrm{~b}, 2 \mathrm{~b}$ & Prosody, sight reading, grammar \\
IV & Latin Prose & $2 \mathrm{~b}, 1 \mathrm{a}, 3 \mathrm{~b}$ & \\
IV & Algebra & $2 \mathrm{~b}$ II, $1 \mathrm{a}$ II, 3b II & \\
IV & Geometry & $4 \mathrm{~b}, 4 \mathrm{bP} * * *, 4 \mathrm{~b}, 3 \mathrm{~b}$ & Grammar, reading, translation \& composition \\
IV & French & $2 \mathrm{~b} \mathrm{~V}, 1 \mathrm{~b} \mathrm{~V}$ & Selected epistles \\
IV & Bible & $3 \mathrm{c}, 2 \mathrm{~b}, 2 \mathrm{~b}$ & \\
V & Oratory & $2 \mathrm{~b}, 2 \mathrm{~b}, 2 \mathrm{~b}, 2 \mathrm{~b}, 1 \mathrm{a}$ & \\
V & English & $1 \mathrm{a}, 2 \mathrm{~b}, 2 \mathrm{~b}, 2 \mathrm{~b}, 1 \mathrm{a}$ & \\
V & U.S. History & $1 \mathrm{a}, 1 \mathrm{a}, 1 \mathrm{a}, 1 \mathrm{~b}$ & \\
V & Algebra & $1 \mathrm{~b} \mathrm{III,} 3 \mathrm{~b} \mathrm{III,} \mathrm{3b} \mathrm{IV,} \mathrm{3b} \mathrm{III,} \mathrm{4b} \mathrm{IV}$ & \\
V & Solid Geometry & $2 \mathrm{~b}, 1 \mathrm{~b}$ & \\
V & German (ADVANCED) & $1 \mathrm{~b}, 1 \mathrm{~b}, 1 \mathrm{~b}, 1 \mathrm{~b}, 1 \mathrm{~b}$ & \\
V & Physics, Text & $3 \mathrm{~b}, 3 \mathrm{c}, 2 \mathrm{~b}, 3 \mathrm{c}, 1 \mathrm{a}$ & \\
V & Physics, Laboratory & $2 \mathrm{~b}, 4 \mathrm{c}, 4 \mathrm{~b}, 4 \mathrm{bP} * * *, 1 \mathrm{a}$ & \\
V & Bible & $3 \mathrm{~b}, 1 \mathrm{~b}, 4 \mathrm{eP} * * *, 2 \mathrm{~b}, 1 \mathrm{a}$ & \\
V & Civics & $2 \mathrm{~b}, 1 \mathrm{a}, 1 \mathrm{a}, 1 \mathrm{a}, 1 \mathrm{a}$ & \\
V & Disobedience & $0,0,0,0,0$ & \\
V & Misconduct & $0,0,0,0,0$ & \\
V & Delinquency & $40,10,35,20,40$ & \\
\hline & & & \\
\end{tabular}

* Note: grade scale unknown (J. Haun, personal communication 9/7/16)

** Macbeth, Milton's Lycidas, Comus, Alllegro, Il Penseroso, Burke's speech on conciliation with America, Macaulay's essays on Milton and Addison.

*** Original colored in red.

As noted in his delinquency marks, Leopold also thrived on daily "tramps" into the woods and fields that then surrounded TLS. His extra-curricular interests in ornithology and botany were encouraged by neighboring Princeton professors and his mother, who sent him a manual of botany as a gift that he used daily (Meine, p. 42, Laubach, passim.).

Leopold's secondary education ended in 1905, when he entered Yale University Sheffield School of Science, to further his stated "dual interests in society and nature" and the "tensions" 
between them (Meine, p. 51), an apt summary of the goals of environmental literacy ever since. In the next section, I show in two brief examples how Leopold's secondary-school curricula in BHS and TLS were sources of knowledge and skills. For space considerations, these are examples from his mature works; his school writings filled with drawings, and marginalia meticulously done in pencil or pen and ink (n.d.) deserve their own reviews (e.g., Laubach, 2005). For instance (n.d., pp. 852 ff.), a position paper in a debate on the abolition of the Army canteen, gives good evidence of his early study of rhetoric.

\section{Humanist Knowledge and Skills in Leopold's Writings}

In his voluminous collected writings (2013), Leopold built and maintained knowledge and skills learned in the humanist curriculum that he encountered at BHS and TLS, and began to use in his school work and letters. One prominent example is in an article published in 1942, in which he argued for a liberal education that combined humanist, social-efficiency and socialmeliorist strands of curriculum. In an address to a North American Wildlife Conference, he stated that professional education for conservationists would face a new crisis after gearing up to deal with crises caused by depression and war. To deal with new demands on land use and wildlife management, he called for fusing professional training with liberal-arts education, as follows:

Liberal education in wildlife is not merely a dilute dosage of technical education. It calls for somewhat different teaching materials and sometimes even different teachers. The objective is to teach the student to see the land, to understand what he sees, and enjoy what he understands. I say land rather than wildlife, because wildlife cannot be understood without understanding the landscape as a whole. Such teaching could well be land ecology rather than wildlife, and could serve very broad educational purposes. 
Perhaps the most important of these purposes is to teach the student how to put the sciences together in order to use them. All the sciences and arts are taught as if they were separate. They are separate only in the classroom. Step out on the campus and they are immediately fused. Land ecology is putting the sciences and arts together for the purpose of understanding our environment (p. 467).

These two paragraphs, written when Leopold was 55 years old, would do proud his high-school English teacher, Miss Rogers, and others who helped him master clear and cogent prose. Leopold's immersion in classical rhetoric is evident from the first sentence, a Ciceronian antithesis that positions an argument by stating its opposite, to the last two sentences that also argue by opposition. Leopold here makes good use of enthymeme, which is defined as "maintaining a truth by showing its opposite" (Lanham, 1991, p. 65). No doubt he had heard this type of logic used many times in his career at Yale, the U.S. Forest Service, and the University of Wisconsin, but certainly he first heard it in the works of Cicero that he declaimed at his boyhood home in Iowa and showed in his position paper on the Army Canteen for a debate at BHS (n.d., pp. 852 ff.).

Another notable example of Leopold's use of enthymeme is in the opening three paragraphs of The Land Ethic section of SCA, in which he compares one type of land-use policy to Odysseus's use of slaves in Homer's Odyssey:

When god-like Odysseus returned from the wars in Troy, he hanged all on one rope a dozen slave-girls of his household whom he suspected of misbehavior during his absence.

This hanging involved no question of propriety. The girls were property. The disposal of property was then, as now, a matter of expediency, not of right and wrong. 
Concepts of right and wrong were not lacking from Odysseus' Greece: witness the fidelity of his wife through the long years before at last his black galleys clove the winedark seas for home. The ethical structure of that day covered wives, but had not yet been extended to human chattels. During the three thousand years which have since elapsed, ethical criteria have been extended to many fields of conduct, with corresponding shrinkages - in those judged by expediency only (p. 171).

As well as showing Leopold's knowledge of Homer's epic by quoting a passage from deep in Book 22, this famous passage in SCA shows his training in logic, because it can be parsed as paired syllogisms. The first is a negative one:
A. Odysseus treated his slaves as property;
B. His ethical structure did not extend to property;
C. Therefore, his ethical structure did not apply to slaves.

Leopold then declares that ethical criteria have demonstrably evolved and been extended, in a sentence that lands with emphasis on evolution as the reason why ethics have changed since the era of Odysseus:

This extension of ethics, so far studied only by philosophers, is actually a process in ecological evolution (ibid.)

By the end of the third paragraph, Leopold has offered examples of ethical evolution from the Mosaic Decalogue to the Golden Rule, leading to the "ethical possibility and evolutionary necessity" of extending ethics to all humans and to land, which he defines as a community that encompasses all living things along with the environments they inhabit. He then offers a second and positive syllogism:

A. Evolution makes things change; 
B. Ethical structures evolve;

C. Therefore, ethics change to extend over all beings and land.

This passage shows that Leopold had acquired the skills of Ciceronian debate taught in the BHS curriculum and the curricula of logic, elocution, and oratory taught at TLS.

A second example of Leopold's mastery of knowledge and skills imparted in his classical humanistic curricula is in a subtle exegesis of the Book of Genesis. As Callicott (1999) and Smaje (2008) have contended, Leopold introduced in TLE a reading of that scripture in which post-lapsarian humans are neither dominators nor stewards of creation, but, as he plainly says, “... from conqueror of the land-community to plain member and citizen of it" (p. 173).

Along with pairs of antonyms (e.g., Type A versus Type B, sword versus searchlight, King or not, etc.), Leopold inserts after "conqueror" two synonyms: "plain member and citizen". Apart from many other implications he was drawing as this essay came to a close, he took care to use a version of tricolon (Lanham, 1991, p. 154) an ancient rhetorical technique he probably first encountered in his secondary-school curricula and enshrined in the eleventh to fourteenth words of his most famous turn of phrase, "A thing is right when it tends to preserve the integrity, stability, and beauty of the biotic community. It is wrong when it tends otherwise" (p. 188). This oft-repeated phrase gains some of its resonance from Leopold's deployment of both tricolon and enthymeme.

We have a trove of Leopold's collected works from which to draw implications, and a thriving community of scholars to analyze them and apply them to scientific, political, and literary studies. We know that he was exposed early and often to enthymemes, syllogisms, and tricolons as models of elocution in classical and modern languages before he began advanced studies. And we know that the power and durability of his ideas flow from twin fountains of 
scientific knowledge and humanist eloquence, a confluence of two major streams of curriculum theory. In the next section, I ask how contemporary educators can follow Leopold's maxim to evolve ethical ideas "in the minds of a thinking community" (p. 188).

\section{Humanist Curricula in Environmental Education}

In 1942, Leopold declared, “... what is science? Only categories for thinking. ... What is art? Only the drama of the land's workings" (p. 468). In calling for a synthesis of curriculum in land ecology, he was responding to increased specialization and professionalization in wildlife management. He foresaw the shortcomings of training graduate students for jobs and salaries at the expense of a continuing liberal education. He decried the market-based policies of many programs, and that they should be "... putting sciences and arts together for the purpose of understanding our environment" (p. 467).

In this section, I briefly survey the field of environmental education (EE) to ask whether Leopold's call for synthesis is occurring in secondary school curricula for EE.

In middle grades, where Leopold first encountered formal nature study, the National Environmental Education Foundation (NAAEE; 2015) reported:

Eighth-graders outscore sixth-graders on knowledge and skills, while sixth-graders top eighth-graders in affective and behavior measures. This suggests that students gain ecological knowledge as they mature, but increasing sensitivity or action does not necessarily accompany this growing knowledge (p. 39).

By one measure, environmental literacy rates in the US have not markedly improved since Coyle's (2005) report:

In a global study of young people's knowledge and attitudes about the environment, students in the United States scored below average for their counterparts in developed 
countries.... The results indicate that American students score below average among OECD nations. While, on average, $19.2 \%$ of young people scored at the highest level of proficiency in environmental science, by contrast, $17.1 \%$ of American students reached this highest level. For reference, $30.9 \%$ of students in Finland scored at this level, along with 28.4 percent of Japanese students, and $26.3 \%$ of Canadian students. On average, $15.5 \%$ of students in all OECD nations scored at the lowest level of proficiency, but $17.3 \%$ of American students fell into this category. Interestingly, young people across the PISA assessment named school as the place where they learn about the environment, more than any other source of information (p. 39).

Coyle's (2005) rueful conclusion without hard data seems to have been borne out by subsequent studies. Universal environmental literacy is not found in the US, as well as in the world.

After approval by an institutional review board and with participants' explicit informed consent, I conducted an informal and anonymous survey of students $(n=10)$ taking environmental-education courses at my university. None reported reading the following texts assigned to Leopold at BHS and TLS in 1899 to 1905, and reportedly not assigned in their comprehensive public high schools in 2012 to 2017 :

- Aeneid, by Vergil;

- Gallic Wars, by Caesar;

- Selections from the works of Cicero.

In addition, the following texts were in Leopold's home library and the library at TLS, but reportedly were neither assigned nor read:

- Faust, by Goethe;

- Kosmos, by von Humboldt. 
Three texts were read and assigned in both Leopold's schools and reported in contemporary schools:

- Iliad by Homer

- Odyssey by Homer

- Voyage around the World, by Darwin
$45 \%$

$55 \%$

$60 \%$

SCA and three $20^{\text {th }}$-century texts were also reportedly assigned and read:

- Silent Spring by Carson 20\%

- Sand County Almanac by Leopold $\quad 40 \%$

- Nature Writings by Muir $\quad 10 \%$

- Walden by Thoreau $\quad 50 \%$

Finally, $75 \%$ of respondents reported reading the Bible, but not assigned in school as in Leopold's curriculum at TLS.

This small-scale survey nonetheless has an implication for environmental educators interested in using Leopold's education as a model of practice, especially in K-12 schools. Leopold exemplified in his life and works a synthesis of classical languages and literature with contemporary science and technology. He was a student who read voraciously, recited eloquently, and wrote copiously. He also eagerly went outdoors, often with his notebooks in hand, nearly every day of his school career. For effective EE, humanist curriculum theory can co-exist with developmental, social-efficiency and social-meliorist theories.

\section{Two Lessons from Leopold's Curricula}

First, EE curricula can be infused in every subject at every level, in accordance with most curriculum theories. Whether urban, suburban, or rural, public or private, virtual or face-to-face, schools have curricula that undergo continuous processes of deliberation. Choices of what, when 
and how to teach evolve out of expediency but it would be inexpedient to exclude classic languages and literature to emphasize science, technology, engineering, arts, and mathematics (STEAM). Such narrow curricula emphasize preparing students for employment at the risk of impoverishing them of what Leopold call "the drama of the land's workings" (p. 468). The drama that Leopold found in the Odyssey, the Bible, and other classical works can be synthesized with the "ways of thinking" that Leopold found in the sciences, toward the end point "to see the land, to understand what he sees, and to enjoy the land" (ibid.).

Second, modern technology in K-12 schools can amplify curricula for all subjects including EE, in ways that Leopold could only dream about. Students can readily engage in projects on global scales to study Leopold's holistic conception of land as ecological relationships among air, water, soil, wildlife, and humans. Students can also see the island kingdom where Odysseus ruled, or the Roman forum where Cicero spoke. The horizons of $21^{\text {st }}$ century EE can reach beyond the fields of Iowa and New Jersey where Leopold roamed. Students can now view the mountains, rivers, and the shack where he worked, and visit them far more easily than he did. However, there is no substitute for place-based environmental literacy in which, as Leopold declared, arts and sciences are "immediately fused" when students "step out" of classrooms, either physical or virtual. Educators should follow his lead and engage K-12 students with their immediate environments through phenology, botany, and ornithology, along with hunting and fishing (Robbins, Silbernagle, \& Van Deelen, 2015; Smith, 2007). Hands-on field work is as important to environmental literacy in our day as it was in Leopold's. What urban or suburban students lack in immediate access to wilderness and wildlife can be provided by committed educators and their partners (Chang, 2017; Russ, 2015). 


\section{Conclusion}

Both curricula and ethics extend across boundaries and evolve in the minds of their communities. Since the implementation of formal environmental education programs after the first Earth days in the 1970s, when I first encountered Leopold's works, their curricula have evolved and extended to adapt to their changing circumstances. Some obstacles have been surmounted as programs and standards became established; other obstacles have prevented wider adoption and greater results. Environmental education curricula, when fully articulated, combine arts and sciences: humanistic disciplines of literature and history, developmental disciplines of arts and psychology, social-efficiency disciplines of sociology and engineering, and socialmeliorist disciplines of politics, sciences, and technologies.

In his 1942 address, the name that Leopold chose for such combinations was liberal arts. As Kliebard summarized liberal-arts curricula:

...the liberal-arts [curriculum] does not reject utility: it seeks a broader and grander utility than is represented by the specific and immediate. It is a utility that lies, broadly speaking, in the development of rationality and the freedom that rationality provides to discover why I should believe and act as I do (1992, p. 47).

In other words, a key lesson from Leopold's education at Burlington High School and The Lawrenceville School is that curricula for environmental education extend across interdisciplinary liberal arts and sciences. Their purposes are many, but all point toward the ends that Leopold and Kliebard both stated: to ask what, how, and why our environment works, and to enjoy it to the fullest within boundaries of reason and ethics. A model environmental-education curriculum should be what young Aldo Leopold had: reading, writing, drawing, and speaking in his schoolrooms, then taking his manuals and notebooks outside into woods and fields. 


\section{References}

Buell, L. (2001). Writing for an endangered world: Literature, culture, and environment in the U.S. and beyond. Cambridge, MA: Harvard University Press.

Callicott, J. B, (Ed.). (1999). Beyond the land ethic. Albany, NY: State University of New York Press.

Chang, D. (2017). Diminishing footprints: Exploring the local and global challenges to placebased environmental education. Environmental Education Research, 23(5),723-732.

Coyle, K. (2005). Environmental literacy in America: What ten years of NEETF/Roper research and related studies say about environmental literacy in the U.S. Washington, DC: National Environmental Education \& Training Foundation.

Fultz, F. (1904). Report of the superintendent of public schools. Burlington, IA: Burlington School District.

Kliebard, H. (1992). Forging the American curriculum. New York, NY: Routledge.

Kliebard, H. (1995). The struggle for the American curriculum, $2^{\text {nd }}$ ed. New York, NY: Routledge.

Lanham, R. (1991). A handlist of rhetorical terms, $2^{\text {nd }}$ ed. Berkeley, CA: University of California Press.

Laubach, S. (Ed.). (2005). When my turn comes: Selections from Aldo Leopold's Lawrenceville letters and journals: Lawrenceville, NJ: The Lawrenceville School Science Department.

Leopold, A. (2013). A Sand County almanac \& other writings on ecology and conservation (C. Meine, ed.) New York, NY: Library of America.

Leopold, A. (n.d.) Student course materials: High-school class notes, essays, etc. [archive] Retrieved from http://digital.library.wisc.edu/1711.dl/AldoLeopold.ALStuCourse 
Lotz-Sizitka, H., et al. (2013). Traditions and new niches: An overview of environmental education curriculum. In R. Stevenson et al., (Eds.) International handbook of research on environmental education. New York, NY: Routledge.

Meine, C. (2010). Aldo Leopold: His life and work, $2^{\text {nd }}$ ed. Madison, WI: University of Wisconsin Press.

National Environmental Education Foundation. (2015). Environmental literacy in the United

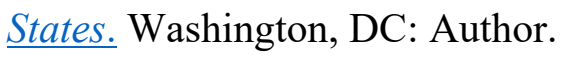

Reese, W. (1999). The origins of the American high school. New Haven, CT: Yale University Press.

Robbins, P., Silbernagle, J., \& Van Deelen, T. (2015). The land ethic reclaimed: Perceptive hunting, Aldo Leopold, and conservation. [web site] https://moocs.wisc.edu/mooc/landethic/

Russ, A. (Ed.) (2015). Urban environmental education. Washington, DC: NAAEE.

Smaje, C. (2008). Genesis and J. Baird Callicott: The land ethic revisited. Journal for the Study of Nature, Religion \& Culture 2.2, 183-198 doi: 10.1558/jsmc.v2i2.183

Smith, G. (2007). Place-based education in the global age: Local diversity. (D. Gruenewald, Ed.). New York, NY: Routledge. 